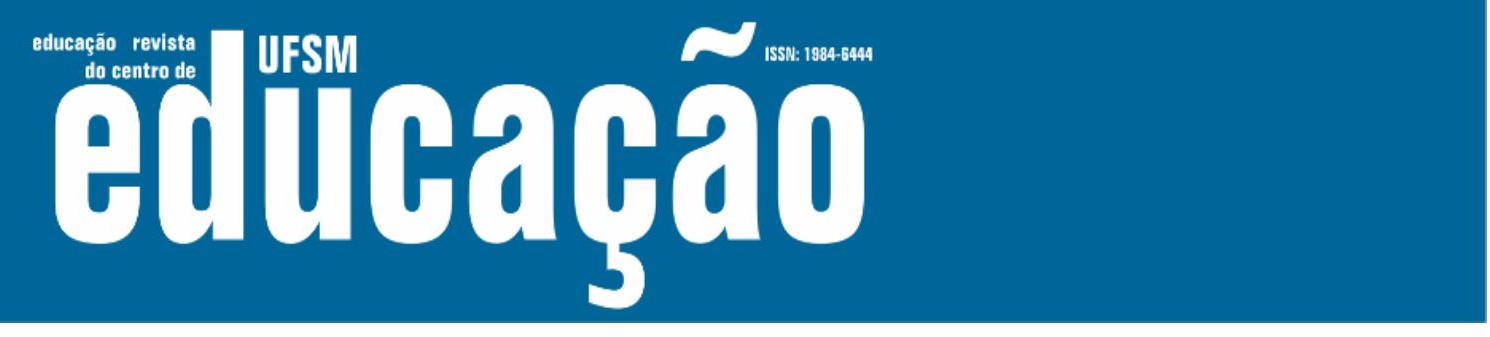

ISSN: 1984-6444 | http://dx.doi.org/10.5902/1984644443344

\title{
O elogio da Literatura
}

\author{
In Prise of Literature
}

\section{Claudionei Vicente Cassol}

Pós-doutorando na Universidade Regional do Noroeste do Estado do Rio Grande do Sul, ljuí, Rio Grande do Sul, Brasil. Professor na URI - Frederico Westphalen-RS, Brasil.

cassol.cv@gmail.com - https://orcid.org/0000-0001-7837-887X

Sidinei Pithan da Silva

Professor doutor na Universidade Regional do Noroeste do Estado do Rio Grande do Sul, ljuí, Rio Grande do Sul, Brasil.

sidinei.pithan@unijui.edu.br - https://orcid.org/0000-0001-6400-4631

Recebido em 04 de abril de 2020

Aprovado em 22 de maio de 2020

Publicado em 31 de julho de 2021

O mundo que compartilhamos revela as compreensões que atores e atrizes das processualidades históricas assumem e desenvolvem cotidianamente. As geografias e o conhecimento colocado à disposição, enquanto construções humanas, acumulam e transportam ações e decisões, aprendizados e validações sociais. A educação, acontecimento necessário, apresenta-se contingente ao indicar possibilidades e carregar intencionalidades das potências formadoras. Essa marcação parece relevante no situar o contexto de acontecimento dos processos educativos na pluralidade do mundo produzido. Talvez, processo supra-democrático, na medida em que não participa, necessariamente, da ágora política.

Zygmunt Bauman, preocupado com a dignidade humana e a vida (ALMEIDA, GOMES; BRACHT, 2009), publica, com Riccardo Mazzeo, O elogio da Literatura (2020), para continuar o diálogo sobre a crise que empareda a educação, iniciado, em 2012, em On Education. A obra vê, no diálogo, uma forma de educar já defendida por Bauman e; também enfatiza a preocupação de Mazzeo com o problema do reprodutivismo. As 151 páginas e 12 capítulos de 0 elogio da Literatura, permitem compreender o mundo em que vivemos, bem como pensar sobre os rumos dos processos educativos formais e não-formais, instituindo compreensões que motivam ações educadoras. A literatura é referida na obra como 


\section{N HEM

ISSN: 1984-6444 | http://dx.doi.org/10.5902/1984644443344

Esse simbólico representa uma totalidade que, teimosamente, apega-se a concepções de valor, de posses, em detrimento de elaborações, sentidos e emoções e, consequentemente, de questionamentos e diálogos que, no movimento centrífugo das elaborações metafóricas, impulsiona para a descoberta das contingências. A cultura hegemônica operou indivíduos forjados nas centralidades de poder e reprodutores (BOURDIEU E PASSERON, 1992), sendo que os processos educativos fortaleceram o paternalismo.

Mazzeo, ao pensar o interregno, apresenta a literatura com possibilidade de atribuir sentido e construir significados potentes na direção de tracejados superadores da condição de vazio no qual "os modos de viver no mundo já não funcionam mais e os novos ainda não foram inventados" (BAUMAN; MAZZEO, 2020, P. 61). As metáforas que emergem da literatura desenvolvem dimensão criadora e promotora de entendimentos que permitem compreender as metamorfoses (BECK, 2018) do mundo. Esta centralidade do capítulo cinco remete ao conteúdo do sexto, ao evidenciar o esvaziamento das forças hermenêuticas, interpretativas e dialógicas na interface das dialéticas da existência.

Os blogs e o desaparecimento das mediações expressam a "geração vazia" em expansão monstruosa também em função da ruptura das possibilidades de veiculação de conteúdo significativo e criativo, com acessos constantes, buscas expressivas e consultas de impacto. O capítulo sexto conecta-se ao primeiro, ao articular a concepção das duas irmãs: sociologia e literatura. Mazzeo e Bauman ocupam-se da "profunda relação entre a literatura e a vida". O centro vazio de poder, ideia de Italo Calvino, questiona as dificuldades para o crescimento humano ante às carências de lideranças e heranças significativas que possam constituir-se guias e portadoras de mensagens de humanidade, solidariedade e pluralidade de sentidos como o amor, a existência, a vida e a natureza humana.

$\mathrm{Na}$ luz do debate da primeira parte do livro, o capítulo sete expõe as mazelas sociais que desenvolvem patologias forçadas pelas normativas do mercado consumista. Poderosas, direcionam compreensões e orientam ações dos indivíduos ao isolamento social e, perigosamente, ao esquecimento da própria condição humana da interação, das experiências diante das incertezas e contingências da 


\section{Autนaดูลิ}

ISSN: 1984-6444 | http://dx.doi.org/10.5902/1984644443344

eles existem e podem ser compreendidos e tratados no horizonte da solidariedade.

Literatura e sociologia alimentam-se para produzir novos horizontes educativos e dialógicos. Abrem possibilidades às críticas, contextos plurais e complexos e revelam as riquezas do diferente. Novas metáforas potencializam discursos, despertam atitudes criativas, artísticas, educadoras de afetividade e solidariedade. O elogio da literatura é valorização da capacidade educadora que as narrativas, ricas em metáforas, detêm, pois produzem possibilidades de sonhos e esperanças, agência (auto) crítica e cultural no mundo. O problema com nossa civilização, insiste Bauman a partir de Castoriadis, "é que ela parou de se questionar" (MAZZEO; BAUMAN, 2020, p.138). O mais importante para educação em sua tarefa ética e política é: 1) permanentemente questionar a mesmice e o conforto mental, "de uma vida apressada e vivida sob a tirania do momento" (MAZZEO; BAUMAN, 2020, p.143), e; 2) despertar o sentido de escolha e responsabilidade com o destino do mundo humano, social e histórico.

\section{Referências}

ADORNO, Theodor. Crítica de la cultura y sociedade I: Obra completa, 10/1, Prismas, Sin imagen directriz. Madrid, España: Ediciones Akal, S. A: 2008.

ADORNO, Theodor. Minima Moralia. Lisboa, Portugal: Edições 70, 2001.

ALMEIDA, Felipe Quintão de; GOMES, Ivan Marcelo; BRACHT, Valter. Bauman \& Educação. Belo Horizonte: Autêntica, 2009.

BAUMAN, Zygmunt. A Cultura no mundo líquido moderno. Rio de Janeiro: Zahar, 2013.

BAUMAN, Zygmunt. On education: conversations with Riccardo Mazzeo. Malden, USA: Polity Press, 2012.

BAUMAN, Zygmunt; DESSAL, Gustavo. El retorno del péndulo: sobre psicoanálisis y el futuro del mundo líquido. Buenos Aires: Fondo de Cultura Económica, 2014.

BAUMAN, Zygmunt; MAZZEO, Riccardo. Elogio da literatura. Rio de Janeiro: Zahar, 2020. 


\section{usp

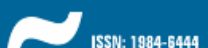

ISSN: 1984-6444 | http://dx.doi.org/10.5902/1984644443344

BOURDIEU, Pierre; PASSERON, Jean-Claude. A reprodução: elementos para uma teoria do sistema de ensino. Rio de Janeiro: Francisco Alves, 1992.

DUSSEL, Enrique. Ética da libertação na idade da globalização e da exclusão. 2.ed. Petrópolis : Vozes, 2002.

ENDE, Michael. História sem fim. São Paulo: Martins Fontes, 2000.

FRIGOTTO, Gaudêncio. Educação e formação humana: ajuste neoconservador e alternativa democrática. In: GENTILI, Pablo Antonio Amadeo; SILVA, Tomaz Tadeu da. (org). Neoliberalismo, qualidade total e educação: visões e críticas. Rio de Janeiro: Vozes, 2002. P. 31-92.

HORKHEIMER, Max. Eclipse da razão. São Paulo: Centauro, 2000.

ORWELL, George. 1984. São Paulo: Companhia das Letras, 2009.

PLATÃO. A República. Livro VII. Rio de Janeiro: Nova Fronteira, 2014.

SAVATER, Fernando. O valor de educar. São Paulo: Planeta, 2005.

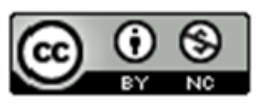

This work is licensed under a Creative Commons Attribution-NonCommercial 4.0 International (CC BY-NC 4.0) 